\title{
NONTHYROIDAL ILLNESS SYNDROME IN PATIENTS WITH SUBARACHNOID HEMORRHAGE DUE TO INTRACRANIAL ANEURYSM
}

\author{
Luiz Augusto Casulari', Paola Mangieri², Luciana A. Naves³, \\ Kunio Suzuki², Moema Ferreira ${ }^{4}$, Lucilia Domingues ${ }^{3}$
}

\begin{abstract}
We have previously reported that subarachnoid hemorrhage due to ruptured intracranial aneurysm (SH) is associated with changes in the hormonal profile in the first 24 hours after the event. We proposed that the hormonal changes observed are due to the intense stress to which the patients are exposed. However, the thyroidal hormonal profile is indicative of the presence of a nonthyroidal illness syndrome (NTIS). In this paper, we examined whether the change in the thyroid hormone profile is compatible with a NTIS. Two groups of patients were included in the study: A) 30 patients with SH (21 females and 9 males; $41.7 \pm 11.4$ years) and B) a control group including 25 patients with benign diseases of the spine (BDS) (lumbar disc hernia or stable spinal trauma) ( 8 females and 17 males; $41.3 \pm 14.2$ years). In a subgroup of eight patients of each group serum triiodothyronine (T3) and reverse T3 levels were measured. The blood samples were obtained between 8:00 and 9:00 AM. The following results were obtained: The SH group had smaller serum T3 and free T4 levels than the BDS group $(\mathrm{p}<0.05)$ : T3 $(\mathrm{ng} / \mathrm{mL}): \mathrm{SH}=58.7 \pm 1.1$ and $\mathrm{BDS}=74.5 \pm 13.9$; free $\mathrm{T4}(\mathrm{ng} / \mathrm{dL})$ : $\mathrm{SH}=0.9 \pm 0.2$ and $\mathrm{BDS}=1.1 \pm 0.3$. There was no significant difference in the serum levels of total thyroxine (T4) and thyroid-stimulating hormone (TSH) between the two groups: T4 $(\mu \mathrm{g} / \mathrm{dL}): \mathrm{SH}=6.9 \pm 1.1$ and BDS $=7.4 \pm 2.1 ; \mathrm{TSH}(\mu \mathrm{Ul} / \mathrm{mL}): \mathrm{SH}=1.5 \pm 0.8$ and $\mathrm{BDS}=1.8 \pm 1,0$. In the sample of eight patients of each group we had the following results: $\mathrm{T3}(\mathrm{ng} / \mathrm{mL})$ : $\mathrm{SH}=66.8 \pm 3.8$ and $\mathrm{BDS}=77.2 \pm 1.1 \mathrm{(p}$ $<0.05)$; reverse $\mathrm{T3}(\mathrm{ng} / \mathrm{dL})$ : $\mathrm{SH}=32.8 \pm 8$ and $\mathrm{BDS}=24.7 \pm 2.2(\mathrm{NS}) ; \mathrm{T} 3 /$ reverse $\mathrm{T} 3$ ratio: $\mathrm{SH}=2.6 \pm 0.3$ and $\mathrm{BDS}$ $=3.3 \pm 0.4$ (NS). Thyreoglobulin and microsomal antibodies were not detectable, except in one patient in the SH group. In conclusion, the SH patients present serum levels of T3 and free T4 significantly lower than that of BDS patients; the thyroidal hormone profile suggests that $\mathrm{SH}$ patients have developed the nonthyroidal illness syndrome.
\end{abstract}

KEY WORDS: cerebral aneurysm, euthyroid sick syndrome, nonthyroidal illness syndrome, subarachnoid hemorrhage, thyroid hormones.

\section{Sindrome da doença não tiroideana em pacientes com hemorragia subaracnoidea devida a aneurisma cerebral}

RESUMO - Nós apresentamos previamente que a hemorragia subaracnoidea devido à ruptura de aneurisma intracraniano (SH) está associada com alterações no perfil hormonal nas primeiras 24 horas após o evento. Nós propusemos que as alterações hormonais observadas são devidas ao intenso estresse ao qual os pacientes estão expostos. Contudo, o perfil hormonal tireoidiano é indicativo da presença da síndrome da doença não tireoidiana (NTIS). Neste trabalho, examinamos se as alterações no perfil dos hormônios tireoidianos são compatíveis com a NTIS. Dois grupos de pacientes foram incluídos no estudo: A) 30 pacientes com SH (21 mulheres e 9 homens; $41,7 \pm 11,4$ anos) e B) um grupo controle incluindo 25 pacientes com doenças benignas da coluna (BDS) (hérnia de disco lombar ou estável trauma da coluna) (8 mulheres e 17 homens; $41,3 \pm 14,2$ anos). Em um subgrupo de oito pacientes de cada grupo os níveis séricos de triiodotironina (T3) e T3 reverso foram medidos. As amostras de sangue foram obtidas entre 8:00 e 9:00. Os seguintes resultados foram obtidos: o grupo SH teve menores níveis de T3 e T4 livre do que o grupo BDS $(p<0,05):$ T3 (ng/ml): SH = 58,7 $\pm 1,1$ e BDS = 74,5 $\pm 13,9 ;$ T4 livre (ng/dl): $S H=0,9 \pm 0,2$ e BDS = 1,1 $\pm 0,3$. Não ocorreram diferenças significativas nos níveis de tiroxina total (T4) e de hormônio estimulante da tireóide (TSH) entre os dois grupos: T4 ( $\mu \mathrm{g} / \mathrm{dl})$ : $\mathrm{SH}=6,9 \pm 1,1$ e BDS $=7,4 \pm 2,1 ; \mathrm{TSH}(\mu \mathrm{Ul} / \mathrm{ml})$ : $\mathrm{SH}=1,5 \pm 0,8$ e BDS = $1,8 \pm 1,0$. $\mathrm{Na}$ amostra de oito pacientes de cada grupo tivemos os seguintes resultados: $\mathrm{T} 3$ ( $\mathrm{ng} / \mathrm{ml}): \mathrm{SH}=$ $66,8 \pm 3,8$ e BDS $=77,2 \pm 1,1$ ( $p<0,05)$; T3 reverso (ng/dl): $\mathrm{SH}=32,8 \pm 8$ e BDS $=24,7 \pm 2,2$ (NS); relação T3/ T3 reverso: $\mathrm{SH}=2,6 \pm 0,3$ e $\mathrm{BDS}=3,3 \pm 0,4$ (NS). Anticorpos antitireoglobulina e antimicrossomal não foram

Neurosurgery Unit of the Hospital de Base do Distrito Federal (HBDF) Brasília DF, Brazil: ${ }^{1}$ Neurosurgery Unit, HBDF, Escola Superior em Ciências da Saúde; ${ }^{2}$ Neurosurgery Unit, HBDF; ${ }^{3}$ Faculty of Medicine, Brasilia University; ${ }^{4}$ Laboratory of Hormone, HBDF.

Received 3 July 2003, received in final form 15 September 2003. Accepted 24 October 2003.

Dr. Luiz Augusto Casulari - Unidade de Neurocirurgia Hospital de Base do Distrito Federal SMHS Quadra 101 - 70335-900 Brasília DF - Brasil. E-mail: roxomotta@ambr.com.br 
detectáveis, exceto em um paciente no grupo SH. Em conclusão: os pacientes com SH apresentam níveis séricos de T3 e T4 livre significativamente menores do que aqueles com BDS; o perfil hormonal tireoidiano sugere que os pacientes com SH desenvolvem a síndrome da doença não tireoidiana.

PALAVRAS-CHAVE: aneurisma cerebral, hemorragia subaracnóidea, hormônio tiróide, síndrome do doente eutiroideo, síndrome da doença não tiroidiana.

In a previous paper we showed that during the first 24 hours after a spontaneous subarachnoid hemorrhage due to a rupture of an intracranial aneurysm (SH), the patients presented a hormonal secretion profile characterized by an increased cortisol serum level in all patients, prolactin levels higher than normal in a few patients, and normal levels of follicle stimulating hormone (FSH) and luteinizing hormone (LH) (according to the age and sex). In relation to the thyroid hormones we observed a decrease of the triodiodothyronine (T3) levels in a large part of the patients, but in the presence of normal levels of total thyroxine (T4) and thyroid-stimulating hormone (TSH) in most of the cases ${ }^{1}$. This hormonal profile could be explained by the intense stress to which the patients are submitted during the first 24 hours following $\mathrm{SH}^{1}$. However, the thyroidal hormonal profile of SH patients suggests that they might have developed a Nonthyroidal Illness Syndrome (NTIS), a currently preferred designation because it does not involve the definition of the metabolic state of the patient ${ }^{2}$. Based on the assumption that patients with that abnormality are not hypothyroid, in spite of the low T3 level, that condition is also denominated Euthyroid Sick Syndrome or low-T3 syndrome ${ }^{2-4}$. The main laboratory characteristics of NTIS is a decrease of the serum T3, accompanied by an increase of T3 reverse levels, associated or not with normal levels of TSH and total T42-4. The fall of T3 serum concentrations is due to the decrease of the conversion of T4 to T3 in the peripheral tissue, including liver and kidneys, that are responsible for the genesis of T3 which maintains the physiologic circulating levels of this hormone $2,3,5$. Another step which might affect the transformation of T4 into T3 is the difficulty of T4 entrance into the cell where it is metabolized ${ }^{6-8}$.

Concomitantly with the decrease of the T3 serum levels, an increase of the reverse T3 concentrations might occur. This increase is probably produced by a decreased metabolism of reverse T3, due to the reduction of the $5^{\prime}$ - monodeiodinase activity, but also by an increased rT3 production from T4 $4^{2,3}$. The conversion of T4 into T3 and the deiodination of reverse T3 seem to be catalyzed by the same enzyme. If this enzyme is inhibited, a reduction in the T3 serum level might be observed, in parallel with an increase in the reverse T3 serum concentrations ${ }^{9}$. NTIS has been demonstrated in patients with septicemia, acute myocardial infarction, severe chronic diseases and in patients subjected to complex surgeries ${ }^{2-4}$. It has been discussed whether NTIS could be interpreted as a beneficial adaptive response of the organism to spare calories and protein inducing an hypothyroid state. However, patients with NTIS in the mildest form have reduced serum T3 levels, but without clinical signs of hypothyroidism ${ }^{2,10}$. Moreover, it is not clear if the decrease of the serum T3, in absence of decrease in T4 levels, would result in some adverse effect in the organism, or if it is associated with increase in the mortality ${ }^{11}$. The need of thyroid hormone replacement in the patients with NTIS is controversial. The administration of T4 or T3 does not affect the prognosis of seriously sick patients ${ }^{12-14}$, but it has been proposed that the thyroid hormone replacement may be beneficial in some patients ${ }^{2}$.

The aim of the present study is to evaluate the hormonal thyroid profile in patients with $\mathrm{SH}$ in the first $24 \mathrm{~h}$ after the ictus and to determine whether their hormonal profile is compatible with NTIS. A group of patients with benign diseases of the spine served as controls. To our knowledge, this is the first study performed to evaluate the possible presence of NTIS in patients affected by subarachnoid hemorrhage due to a ruptured intracranial aneurysm.

\section{METHOD}

Patients - Two groups of patients hospitalized at the Neurosurgery Unity of the "Hospital de Base do Distrito Federal" were included in the study from August to December 2000. The first group was composed of 30 patients with spontaneous subarachnoid hemorrhage due to a ruptured cerebral aneurysm (SH): 21 females and 9 males, aged $41.7 \pm 11.4$ years on average. According the Hunt \& Hess scale ${ }^{15}$ nine patients were classified as belonging to grade I, thirteen to grade II, and eight to grade III. The second group was compo- 
sed of 25 patients with benign diseases of the spine (BDS) (lumbar disc hernia or stable spinal trauma): eight females and 17 males, aged $41.3 \pm 14.2$ years on average. The difference between the age of SH and of BDS patients was not statistically significant. Serum T3 and reverse T3 levels were evaluated in $8 \mathrm{SH}$ and $8 \mathrm{BDS}$ patients: six females and two males with $\mathrm{SH}$ and two females and six males with BDS. These 16 patients were included in the study in November.

The diagnosis of $\mathrm{SH}$ was based on anamnestic and physical findings and on the brain computerized tomography. The presence of the aneurysm was determined by a four-vessel conventional x-ray angiography (both carotids and both vertebral arteries) through femoral artery catheterism. At admission to the hospital the patients were evaluated clinically and classified according to the Hunt \& Hess scale ${ }^{15}$. Before discharge they were also evaluated by the prognostic Glasgow scale ${ }^{16}$. The diagnosis of BDS was made by anamnestic and physical findings and by spine computerized tomography and/ or magnetic resonance imaging. All the patients were followed until discharged from the hospital.

The inclusion criteria utilized for SH patients were: spontaneous subarachnoid hemorrhage due to a ruptured cerebral aneurysm; grade I to III in the Hunt \& Hess scale; absence of associated systemic diseases, such as renal, heart or respiratory failure and diabetes mellitus. The exclusion criteria for SH patients were: non aneurysmatic subarachnoid hemorrhage; grade IV and $V$ of the Hunt \& Hess scale; patients with associated systemic diseases or using previously confounding drugs ${ }^{17}$.

The BDS patient inclusion criteria were stable spinal trauma or lumbar disc herniation and absence of associated systemic diseases. The BDS patient exclusion criteria were: patients with other spine diseases; associated systemic diseases or use of confounding drugs ${ }^{17}$.

Hormonal assays - Blood samples were collected before angiography and surgery, at the time between 8 and 9 AM, within 24 hours from ictus, centrifuged at $3000 \mathrm{rpm}$, for 10 minutes; serum was stored at $-20^{\circ} \mathrm{C}$ until assayed. Laboratory evaluations were done by commercial kits: T3, T4, free T4, and TSH were assayed by immunofluorimetry (Autodelphia - São Paulo); reverse T3 by radioimmunoassay (Gemels - São Paulo); antithyreoglobulin and antimicrosomal antibodies by indirect hemoagglutination (Bayer - São Paulo).

Statistical analysis - Data were analyzed by KruskalWallis test for independent groups; the level of significance was fixed at $p<0.05$. The results are presented as mean \pm standard error $(\mathrm{M} \pm \mathrm{SE})$.

This study was approved by the Committee of Ethics in Research of the "Secretaria de Estado de Saúde do Distrito Federal". Patients or their legal representatives signed the informed consent for participation in the study.

\section{RESULTS}

As shown in Table 1, T3 and free T4 levels were lower in the SH than in BDS patients $(p<0.05)$. T4 levels were also lower in the SH than in the BDS patients, but this difference was not statistically significant. TSH levels were similar in both groups.

In the individual analysis, it can be appreciated that $12(40 \%)$ patients of the SH group had T3 levels lower than normal, while none of the BDS group had reduced levels. TSH, total T4 and free T4 levels were normal in all patients of both groups.

Due to observation that patients with $\mathrm{SH}$ had T3 and free T4 serum levels lower than those with BDS (Table 1), we analyzed the possibility that the patients with $\mathrm{SH}$ had alterations in the metabolism of the thyroid hormones. Eight patients of each group were studied and the results are shown in Table 2. Serum T3 levels were significantly lower in the $\mathrm{SH}$ group than in the BDS group ( $p<0.01$ ). Serum reverse T3 levels and T3/ reverse $\mathrm{T} 3$ ratio were higher in the patients with $\mathrm{SH}$, but the differences were not statistically significant as compared with BDS patients.

Analyzing these results individually, no patient had T3 levels below of normal range in the both groups; reverse T3 levels were higher than normal range in the two patients of the $\mathrm{SH}$ group, but in none of BDS group; five patients of each group had T3/reverse T3 ratio lower than normal range and in other three patients the levels were normal.

All the patients of this subgroups had normal levels of TSH and total T4 and there was no statistically significant difference between the group means: SH group: $\mathrm{TSH}=1.6 \pm 0.9 \mu \mathrm{U} / \mathrm{mL}$ and $\mathrm{T} 4=$ $7.4 \pm 1.8 \mu \mathrm{g} / \mathrm{dL} ;$ BDS group: $\mathrm{TSH}=1.3 \pm 0.4 \mu \mathrm{U} / \mathrm{mL}$ and $\mathrm{T} 4=7.1 \pm 2 \mu \mathrm{g} / \mathrm{dL}$.

Antithyreoglobulin antibodies were not detected in any patient, while antimicrosomal antibody were present in a single patient of the $\mathrm{SH}$ group who had normal hormonal levels.

\section{Evolution}

All the patients with $\mathrm{SH}$ were submitted to surgical treatment. Most $(70 \%)$ of the patients were finally classified in grade 4 and 5 of the prognostic Glasgow Scale. All the patients with BDS had a favourable evolution.

\section{DISCUSSION}

In a previous paper ${ }^{1}$, we observed that patients with SH have a tendency to show lower T3 
Table 1. Thyroid hormone levels in 30 patients with subarachnoid hemorrhage due to a ruptured intracranial aneurysm and in 25 patients with spine diseases.

\begin{tabular}{lccc}
\hline Hormone & $\begin{array}{c}\text { Subarachnoid } \\
\text { hemorrhage }\end{array}$ & Spine diseases & Normal range \\
\hline $\mathrm{T} 3(\mathrm{ng} / \mathrm{dL})$ & $58.7 \pm 1.1 *$ & $74.5 \pm 13.9$ & 45 to 137 \\
$\mathrm{~T} 4(\mu \mathrm{g} / \mathrm{dL})$ & $6.9 \pm 1.1$ & $7.4 \pm 2.1$ & 4.5 to 12 \\
Free $\mathrm{T} 4(\mathrm{ng} / \mathrm{dL})$ & $0.9 \pm 0.2 *$ & $1.1 \pm 0.3$ & 0.7 to 1.9 \\
$\mathrm{TSH}(\mu \mathrm{Ul} / \mathrm{mL})$ & $1.5 \pm 0.8$ & $1.8 \pm 1.0$ & 0.5 to 4.7 \\
\hline${ }^{*} \mathrm{p}<0.05$ & & &
\end{tabular}

serum levels than expected. Such impression was confirmed in the present study, where T3 levels were significantly lower than those found in patients with BDS. We also observed that the patients with SH had lower free T4 serum levels than those with BDS and that the reverse T3 serum levels showed a tendency to be higher in $\mathrm{SH}$ patients, as compared with those of BDS patients. TSH and total T4 serum levels were normal in both groups of patients. The absence of antibodies against thyroid might be considered indicative of the absence of primary hypothyroidism. This hormonal pattern observed in patients with $\mathrm{SH}$ confirms our initial hypothesis that these patients may develop NTIS.

The main hormonal alteration in NTIS is a decrease of the T3 serum levels. T3 is the thyroid hormone more active in the body, possessing 3 to 4 times more metabolic potency than T4. T3has indispensable importance in lipid and carbohydrate metabolisms and in the generation of energy. It is produced by the thyroid, but its principal origin $(80 \%)$ is the deiodation of the distal ring of T4 in the peripheral tissue ${ }^{9}$.

Three classes of iodothyronine deiodinases produce T4 deiodination. The most important pathway for T4 metabolism is its outer ring $\left(5^{\prime}\right)$ monodeiodination to the active thyroid hormone T3, catalyzed by type 1 and type 2 deiodinases.

The type I enzyme is present in the thyroid, liver, and kidneys, and it is responsible for most of T3 found in the plasma. Type II enzyme has a limited activity, it is present at the level of the central nervous system, pituitary, and brown fat tissue. Type III enzyme produces inner ring deiodination, and it is found in the placenta, skin, and brain. This enzyme removes the iodine of the radical tyrosil of T4 or of T3, originating the inacti-
Table 2. Serum T3 and reverse T3 levels and T3/reverse T3 ratio in eight patients with subarachnoid hemorrhage due to a ruptured intracranial aneurysm and in eight patients with benign diseases of the spine.

\begin{tabular}{lccc}
\hline Normal & T3 $(\mathrm{ng} / \mathrm{dL})$ & reverse T3 & T3/reverse T3 \\
range & $(45$ to 137$)$ & (ng/dL) & $(3,4$ to 5,6$)$ \\
& & $(8$ to 40$)$ & \\
\end{tabular}

Subarachnoid hemorrhage

$\begin{array}{llll}\text { MFS } & 59 & 25.2 & 2.3 \\ \text { OB } & 75 & 84.6 & 0.8 \\ \text { MD } & 46 & 13.5 & 3.4 \\ \text { JSF } & 72 & 31.6 & 2.7 \\ \text { ML } & 59 & 14.2 & 4.1 \\ \text { GS } & 72 & 44.2 & 1.6 \\ \text { MIS } & 76 & 24.8 & 3.0 \\ \text { MLG } & 76 & 24.5 & 3.4 \\ & & & \\ \text { Mean } \pm \text { SD } & 66.8 \pm 3.8^{*} & 32.8 \pm 8 & 2.6 \pm 0.3\end{array}$

Benign disease of the spine

$\begin{array}{llll}\text { JP } & 80 & 16.6 & 4.8 \\ \text { MD } & 76 & 28.3 & 2.6 \\ \text { SB } & 72 & 31.5 & 2.2 \\ \text { MJP } & 82 & 14.4 & 5.6 \\ \text { JC } & 76 & 21.9 & 3.4 \\ \text { AM } & 77 & 28.5 & 2.7 \\ \text { CG } & 80 & 28.5 & 2.8 \\ \text { DM } & 75 & 28.2 & 2.6\end{array}$

$\begin{array}{llll}\text { Mean } \pm S D & 77.2 \pm 1.1 & 24.7 \pm 2.2 & 3.3 \pm 0.4\end{array}$

${ }^{*} p<0.01$ Vs. benign pathology of the spine 
ve metabolites reverse $\mathrm{T} 3$ and iodotironine, respectively ${ }^{9}$

The inhibition of the type I enzyme activity, that converts $\mathrm{T4}$ to $\mathrm{T3}$, is the probable cause of the T3 serum levels reduction in NTIS ${ }^{2-4}$. This enzyme is selenium dependent and the deficiency of this oligoelement has been described in the patients with NTIS ${ }^{18}$. We have previously described an increase in cortisol serum levels in patients with $\mathrm{SH}^{1}$ which can play a role in the NTIS pathophysiology. Pharmacological doses of glucocorticoids block the conversion of T4 to T3, increasing the conversion to reverse $T 3^{9,19}$. TNF alpha ${ }^{20}$ and IL- $6^{21}$ might also be involved in the blockade of the type I enzyme in those patient with NTIS, as indicated by Michalaki et al.22. Another mechanism that can interfere in the transformation of T4 to T3 in NTIS, might be the difficulty of T4 to enter the cells to be metabolized by the type I enzy$\mathrm{me}^{6-8}$. Parallel to the decrease of T3 levels, an increase of the levels of reverse T3 occurs in the patients with NTIS2. This is because the same type I enzyme that transforms T4 in T3, also produces the degradation of reverse $\mathrm{T}^{9}$. As this enzyme is inhibited in NTIS, a reduction of the T3 serum levels and an increase in the reverse T3 serum concentrations might be observed. Reverse T3 is produced exclusively from metabolism of $\mathrm{T} 4$ and its blood concentrations reflect a combination of this metabolic process and its degradation ${ }^{3}$.

Our data show that there was an increase of the reverse $\mathrm{T} 3$ levels in the patients with $\mathrm{SH}$, as compared with those with BDS, but this difference was not statistically significant. As the blood samples were taken within 24 hours after the ictus, it is possible to suppose that a an alteration of the metabolism of reverse T3 already exists in the first hours after SH and that it can probably become more consistent with the progression of the clinical picture. In fact, it has been described that the changes in the reverse T3 levels are correlated with the chronicity and gravity of the diseases $^{2-4,11,23}$.

Our patients had normal total T4 levels, as it has been described in the majority of patients affected by NTIS ${ }^{3}$. This syndrome can be divided into three categories, depending on the levels of total T4, which can be normal, low, or high ${ }^{3}$. The first category with normal total T4 levels represents the great majority of the patients. These patients usually have less serious diseases, as in the case of those included in the present study, who are in the first ranks of the Hunt \& Hess scale.

The second category of NTIS is associated to the decrease of the total T4 levels, as in the case of the two patient with $\mathrm{SH}$ described in the previous paper ${ }^{1}$. The decrease of the T4 levels in NTIS are probably due to a decreased $\mathrm{T} 4$ production (decreased hypothalamic TRH secretion) and to an increase of its metabolic clearance ${ }^{5,10,11}$. Total T4 serum levels are reduced in proportion to the severity and, probably, to the duration of the disease $^{5}$. In acute traumas, as well as, in heart bypass surgeries or in short duration fasting, the serum levels of T4 do not decrease. However, with the increase in the severity of the diseases the fall in the T4 levels might be prominent. T4 serum levels below $4 \mathrm{ng} / \mathrm{mL}$ are associated with a $50 \%$ probability of death and with levels below $2 \mathrm{ng} / \mathrm{mL}$ the probability reaches the $80 \%{ }^{5,24}$.

The third category of NTIS is characterized by a decrease of T3 concentrations, but by increased levels of T4. These patients are usually affected by systemic diseases and their thyroid hormone levels go back to the normal, after improvement of the primary disease ${ }^{2,3}$. This picture can be confused with T4 thyrotoxicosis, but in the latter situation the clinical evidence of an associated hyperthyroidism is also present. We did not have any patient with high levels of T4 in the present, as well as in the previous study. This is confirmatory of the fact that this last category of NTIS is less frequent and not so well defined ${ }^{3}$.

Free T4 represents the fraction of the hormone that is used by the peripheral tissues. The levels of free T4 in NTIS are dependent on the assay method used and can be influenced by inhibitors present in the serum or by agents such as drugs, metabolites or free fatty acids present in the serum or in the assay ${ }^{2}$. Most of the studies present levels of free T4 normal or low ${ }^{11,25}$. Free T4 levels also depend on the total T4 levels; when total T4 levels are normal, the free T4 levels do not appear to be reduced by most of the assay method $^{2}$. This occurred in our patients who presented total and free T4 levels inside of the normal range. However, free T4 levels were reduced in comparison with the BDS control group. A similar situation has been described by other authors ${ }^{26}$.

In our study TSH levels were normal in the patients with SH. TSH serum levels are almost always normal in NTIS, but they have been repor- 
ted to be low or high in some clinical settings $\mathrm{s}^{25-27}$. In our previous study, we have observed that TSH was increased in five patients ${ }^{1}$. It is not totally clear why TSH level might be low or normal in the presence of low circulating T3. It has been suggested that in the latter situation T3 levels in the pituitary might remain normal, due the maintenance of the intra-pituitary deiodination activity, even if in the remaining of the organism T3 formation is reduced ${ }^{4}$.

Another possibility explanation might be an alteration in the TRH secretion by the hypothalamus. It has been described that most of the patients with NTIS have normal TSH responses in the TRH stimulation test ${ }^{4}$. A normal response in the presence of a low basal TSH can suggest an hypothalamic abnormality ${ }^{10,27,28}$. It has been shown that the reduction of the glycosylation process of the TSH molecule makes it immunologically active and biologically inactive and this process is dependent on the TRH levels ${ }^{10,28}$. NTIS is multifactorial and it can differ in different groups of patients. For instance, in patients with hepatic or renal diseases the metabolism of T4 leading to the formation of T3 and reverse T3 may be more seriously compromised ${ }^{2}$, while the patients affected by $\mathrm{SH}$ included in our study had normal renal and hepatic functions. Therefore some of the discrepancies between our study and the others present in the literature can be related to different clinical situations considered.

Great controversy exists on the risks and benefits of the replacement treatment with $\mathrm{T} 4$ and T3 in these patients. De Groot ${ }^{2}$ suggests to use a thyroid hormone replacement in the patients with NTIS on the basis of the following evidences: the production rates of $\mathrm{T} 4$ and $\mathrm{T} 3$ are reduced; the hormone levels in the peripheral tissue are decreased; the substitution hormonal therapy has not shown disadvantages and in some cases it can be beneficial; the administration of physiologic doses of thyroid hormones improves the hormonal blood levels ${ }^{29}$. However, this point of view has not been accepted by other authors because, in the patients with NTIS, the benefit of the thyroid hormone replacement has not been clearly shown ${ }^{30-32}$. The evolution of our patients with $\mathrm{SH}$ was not influenced by the presence of NTIS. All had a good prognosis. It should be taken in consideration that our patients were included in the levels of the Hunt \& Hess scale associated with better prognosis.
We can concluded that the patients with $\mathrm{SH}$ had T3 and free T4 levels significantly decreased in comparison with the patients with BDS; a tendency to show increased levels of reverse T3 was also observed, but the difference versus the patients affected by BDS was not statistically significant; total T4 and TSH levels were not different between the two groups of patients. These results suggest that NTIS is frequent in the patients with $\mathrm{SH}$, while it has not been shown in any of the patients with BDS. The prognosis of patients with $\mathrm{SH}$ grade I to III in the Hunt \& Hess scale is not affected by the presence of NTIS.

Acknowledgment - We acknowledge Mr. Luiz Gustavo Domingues Casulari da Motta for his assistance with preparing the manuscript.

\section{REFERENCES}

1. Mangieri P, Suzuki K, Ferreira M, Domingues L, Casulari LA Evaluation of pituitary and thyroid hormones in patients with subarachnoid hemorrhage due to ruptured intracranial aneurysm. Arq Neuropsiquiatr 2003;61:14-19.

2. De Groot LJ. Dangerous dogmas in Medicine: the nonthyroidal illness syndrome. J Clin Endocrinol Metab 1999;84:151-164.

3. Wastofsky L, Burman KD. Alterations in thyroid function in patients with systemic illness: the "euthyroid sick syndrome". Endocr Rev 1982;3:164-217.

4. McIver B, Gorman CA. Euthyroid sick syndrome: an overview Thyroid 1997;7:125-132

5. Kaptein EM, Robinson WJ, Grieb DA, Nicoloff JT. Peripheral serum thyroxine, triiodotironine and reverse triiodotironine kinetics in the low thyroxine state of acute nonthyroidal illnesses. A noncompartmental analysis. J Clin Invest 1982;69:526-535

6. Sarne DH, Refetoff $\mathrm{S}$. Measurement of thyroxine uptake from serum by cultured human hepatocytes as an index of thyroid status: reduced thyroxine uptake from serum of patients with nonthyroidal illness. J Clin Endocrinol Metab 1985;61:1046-1052.

7. Lim C-F, Docter R, Visser TJ, et al. Inhibition of thyroxine transport into cultured rat hepatocytes by serum of nonuremic critically ill patients: effects of bilirubin and nonseterified fatty acids. J Clin Endocrinol Metab 1993;76:1165-1172.

8. Vos RA, de Jong M, Bernard BF, Docter R, Kenning EP, Hennemann G. Impaired thyroxine and 3,5,3'-triiodothyronine handling by rat hepatocytes in the presence of serum of patients with nonthyroidal illness. J Clin Endocrinol Metab 1995;80:2364-2370.

9. Negri-Cesi P, Celotti F. Le malattie del sistema endocrino. In: Celotti F (ed.) Patologia generale e fisiopatologia. Napoli EdiSES, 2002:629-701.

10. Blake NG, Eckland JA, Foster OJF, Lightman SL. Inhibition of hipothalamic thyrotropin-releasing hormone messenger ribonucleic acid during food deprivation. Endocrinology 1991;129:2714-2718.

11. Kaptein EM, Grieb DA, Spencer CA, Wheeler WS, Nicoloff JT. Thyroxine metabolism in the low thyroxine state of critical non thyroidal illnesses. J Clin Endocrinol Metab 1981;53:764-771.

12. Brent GA, Hershman JM, Braunstein GD. Patients with severe nonthyroidal illness and serum thyrotropin concentrations in the hypothyroid range. Am J Med 1986;81:463-466.

13. Becker RA, Vaughan GM, Ziegler MG, et al. Hypermetabolic low triiodothyronine syndrome of burn injury. Crit Care Med 1982;10:870-875.

14. Klemperer JD, Klein I, Gomez M, et al. Thyroid hormone treatment after coronary-artery bypass surgery. N Engl J Med 1995;333:1522-1527.

15. Hunt WE, Hess RM. Surgical risk as related to time of intervention in the repair of intracranial aneurysms. J Neurosurg 1968:28:14-20.

16. Jennett $B$, Bond M. Assessment of outcome after severe brain damage: a practical scale. Lancet 1975;1:480-484.

17. Surks MI, Sievert R. Drugs and thyroid function. N Engl J Med 1995 333:1688-1694. 
18. Berger MM, Lemarchand-Beraud T, Cavadini C, Chiolero R. Relations between the selenium status and the low T3 syndrome after major trauma. Intens Care Med 1996;22:575-581.

19. Williams DE, Chopra IJ, Orgiazzi J, Solomon DH. Acute effects of corticosteroids on thyroid activity in Grave's disease. J Clin Endocrinol Metab 1975;41:354-361.

20. Nagaya T, Fujieda M, Otsuka G, Yang J-P, Okamoto T, Seo H. A potential role of activated NF-kB in the pathogenesis of euthyroid sick syndrome. J Clin Invest 2000;106:393-402.

21. Boelen A, Platvoet-Ter Schiphorst MC, Wiersinga WM. Association between serum interleukin-6 and serum 3,5,3'-triiodothyronine in nonthyroidal illness. J Clin Endocrinol Metab 1993;77:1695-1699.

22. Michalaki M, Vagenakis AG, Makri M, Kalfarentzos F, Kyriazopoulou V. Dissociation of the early decline in serum T3 concentration and serum IL-6 rise and TNF-alpha in nonthyroidal illness syndrome induced by abdominal surgery. J Clin Endocrinol Metab 2001;86:4198-4205.

23. Chopra IJ, Solomon DH, Hepner GW, Morgenstein AA. Misleading low free thyroxine index and usefulness of reverse triiodothyronine measurement in nonthyroidal illnesses. Ann Intern Med 1979;90: 905-906.

24. Slag MF, Morley JE, Elson MK, Crowson TW, Nuttall FQ, Shafer RB. Hypothyroxinemia in critically ill patients as a predictor of high mortality. JAMA 1981;245:43-45.

25. Melmed S, Geola FL, Reed AW, Pekary AE, Park J, Hershman JM. A comparison of methods for assessing thyroid function in nonthyroidal illness. J Clin Endocrinol Metab 1982;54:300-306.

26. Surks MI, Hupart KH, Pan C, Shapiro LE. Normal free thyroxine in critical nonthyroidal illnesses measured by ultrafiltration of undiluted serum and equilibrium dialysis. J Clin Endocrinol Metab 1988;67: 1031-1039.

27. Fliers E, Guldenaar SEF, Wiersinga WM, Swaab DF. Decreased hypothalamic thyrotropin-releasing hormone messenger ribonucleic acid during food deprivation. J Clin Endocrinol Metab 1997;82:4032-4036.

28. Benker G, Raida M, Olbricht T, Wagner R, Reinhardt W, Reinwein D TSH secretion in Cushing's syndrome: relation to glucocorticoid excess, diabetes, goiter, and the sick euthyroid syndrome. Clin Endocrinol 1990;33:777-786.

29. Hamilton MA, Stevenson LW. Thyroid hormone abnormalities in heart failure: possibilities for therapy. Thyroid 1996;6:527-529.

30. Glinoer D. Comment on dangerous dogmas in Medicine: the nonthyroidal illness syndrome (Letter). J Clin Endocrinol Metab 1999;84: 2262

31. Wastofsky L, Burman KD, Ringel MD. Trading one “dangerous dogma" for another? Thyroid hormone treatment of the "euthyroid sick syndrome" (Letter). J Clin Endocrinol Metab 1999;84:1759.

32. Chopra IJ, Huang TS, Boado R, Solomon DH, Chua Teco GN. Evidence against benefit from replacement doses of thyroid hormones in nonthyroidal illness: studies using turpentine oil-injected rat. J Endocrinol Invest 1987;10:559-564. 